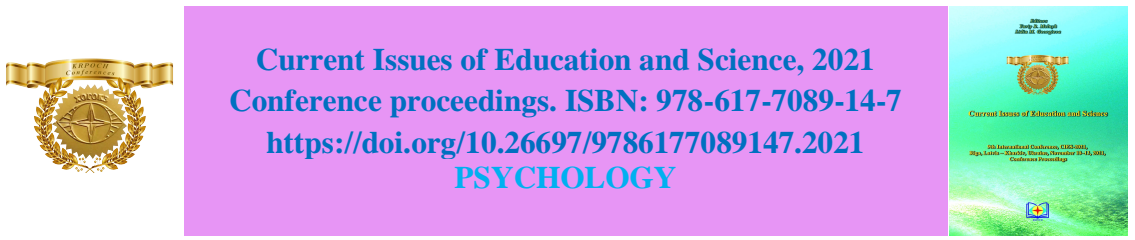

DOI: https://doi.org/10.26697/9786177089147.2021.05

\title{
Problem Issues of the Psychological Science in the Actual Social Dimension
}

\author{
Valerie M. POLISHCHUK ${ }^{1}$ \\ ${ }^{1}$ Borys Grinchenko Kyiv University, Ukraine
}

Corresponding Author Details

Valerie M. POLISHCHUK, valeryipolishchuk@gmail.com

Received: 05.10.2021; Accepted: 02.11.2021; Published: 17.12.2021

\section{Brief Summary}

Background: For analyzing the phenomenon of the "Psychological problems" the search strategies of the psychological science (especially for the study of adult psychology, psychology of the elderly) were formulated, characterized and their expected prospects were identified.

The aim of the study: To explore a structural, structural and functional investigation of its psychological content in terms of the favorable and unfavorable social challenges and threats, and later forecasting.

Methods: Priority among organizational methods is longitude; the main ones are experiment, analytical observation and theoretical modelling.

Results: The obtained theoretical and empirical results should be systematized and organized in their semantic hierarchy: 1) methodological guidelines for understanding the phenomenon (examples: selecting the research priorities, formulating the significant topics, constructing the logistics of the research, modelling); 2) basic content (the conscious need for objective knowledge, or scientific discovery, of humans or social communities). The functional essence of the hypothesis (which significance in the scientific works is devalued at present) was described. The search barriers on the way of cognition to the truth ("problem theorizing", or "bookish education"; "psychology of focusing"; incorrect use of methods 
of the mathematical statistics; formulating contemplative generalizations and conclusions) were defined. It was stated that 1) productive research is a complex informational reflection of the meanings of any problem in three historical chronological aspects of the "past-present-future", 2) modern "current psychological problem issues" suffer the crisis (for example: narrow topics, narrowing the experimental search), 3) modern social demand means the necessity to develop the fundamental and applied technologies for situations of the functional stress, extreme and emergency situations. The importance of the social role of the scientist in researches was shown.

Conclusions: Disregard for the basic meanings of the phenomenon of the "current psychological problem issues" 1) a priori leading to producing the dogmatic, compilated information, 2) discrediting the scientific psychological knowledge.

\title{
Keywords:
}

current problem issues, hypothesis, research, longitude research, modelling, phenomenon.

\section{Проблематика психологічної науки в актуальному соціальному вимірі}

\author{
Валерій М. ПОЛІЩУК ${ }^{1}$ \\ ${ }^{1}$ Київський університет імені Бориса Грінченка, Украӥна \\ Деталі Автора-Кореспондента: \\ Валерій М. ПОЛІЩУК valeryipolishchuk@gmail.com
}

\section{Анотація}

Bcmyn: Для аналізу феномена «психологічна проблематика» сформульовано, охарактеризовано пошукові стратегії психологічної науки (передовсім для вивчення психології дорослості, психології похилого віку) та визначено їхні очікувані перспективи.

Мета дослідження: Структурне, структурно-функиіональне вивчення його психологічного змісту в умовах сприятливих $i$ несприятливих соціальних викликів і загроз, потім - прогнозуванні.

Методи: Пріоритетними серед організаційних методів пріоритетним є лонгітюд; основні - ие експеримент, аналітичне спостереження і теоретичне моделювання.

Результати: Отримані теоретико-емпіричні результати повинні бути систематизовані та впорядковані у свойи смисловій 
ієрархї: 1)методологічні настанови для пізнання феномена (приклади: обрання першочергових дослідницьких пріоритетів, формулювання значущої тематики, побудова логістики іï дослідження, моделювання); 2) базовий зміст (усвідомлена необхідність об'єктивного пізнання, або наукового відкриття, $у$ людини чи сочіальних спільнот). Охарактеризовано функціональну сутність гіпотези, значення якої у наукових роботах зараз знецінене. Визначено пошукові бар'єри на шляху пізнання до істини (“теоретизування проблеми”, або “книжкова вченість”; “психологія фокусу”; некоректне використання методів математичної статистики; формулювання споглядальних узагальнень та висновків). Стверджується, що 1) продуктивне дослідження - ие комплексне інформачійне відображення смислів будь-якої проблеми у трьох історичних хронологічних площчинах "минуле - теперішне майбутне”, 2) сучасна "актуальна психологічна проблематика» знаходиться кризовому стані (приклади: вузька тематика, звуження експериментального пошуку), 3) сучасний сочіальний запит - це необхідність розроблення фундаментальних і прикладних технологій для ситуачій функиіональної напруженості, екстремальних $i$ надзвичайних ситуачій.. Показано важливість сочіальної ролі вченого у дослідженнях.

Висновки: Неврахування базових смислів феномена "актуальна психологічна проблематика" 1) апріорі призводить до продукування догматичної, компілятивної інформачії, 2) дискредитує наукове психологічне знання.

\title{
Ключові слова:
}

актуальна проблематика, гіпотеза, дослідження, лонгітюд, моделювання, феномен.

\section{Присвячується 125-річчю}

\author{
від Дня народження Л. С. Виготського
}

\section{Вступ:}

У XXI ст. парадигма психологічної науки, як вагомий освітній фактор національної безпеки держави, іiі громадян, об'єднаного європейського життєвого простору, має одночасно сконцентрувати i розв'язати актуальні цільові освітні перспективи, або пошукові стратегії, спрямовані на збільшення пізнавальних масштабів свого дослідницького поля, зокрема у психології дорослості, психології людей похилого віку, оскільки вже давно стабілізувалася пізнавальна ситуація, згідно з якою ці життєві етапи не мають навіть мінімальної 
дослідницької уваги порівняно 3 молодшими віковими періодами (Aleksandrov, 2017; Ellis, 2002; Krajg, 2003; Vygotskij, 1984). Окремо знаходиться проблематика вікового кризового розвитку людини, де нормативні і ненормативні кризи тенденційно ототожнюються 3 суміжними стабільними життєвими стадіями. Як наслідок, усталений пошуковий дисбаланс та термінологічний хаос спричиняють аналогічну пошукову ситуацію у повсякденній професійній діяльності суб'єктів психологічного знання.

Мета дослідження. Довести теоретико-практичну необхідність 3'ясування феноменології поняття “актуальна психологічна проблематика" як пізнавального орієнтиру для розвитку психологічної науки у контенті іï цільових освітніх перспектив та нагального (пріоритетного) соціального запиту про життєдіяльність людини в умовах сприятливих і несприятливих соціальних впливів.

\section{Методи:}

Організаційні (пілотний зріз, лонгітюд, поперечний зріз); системно-структурний, історико-логічний та порівняльний аналіз першоджерел про особливості вікового та індивідуального розвитку людини; експеримент, аналітичне спостереження, теоретичне моделювання.

\section{Результати:}

I. Базовий зміст феномена “Актуальна психологічна проблематика" має визначатися анонсованими тут пошуковими стратегіями, які складають пізнавальну альтернативу 1) науковим уявленням про “ідеальну особистість”, коли методологічний принцип «як повинно бути» ігнорує принцип "як є насправді", 2) спорадичним дослідницьким спробам, які, як правило, обмежені у календарному часі і “замикаються” на локальних чи нерепрезентативних вибірках, що призводить до продукування “загального знання" про людину, 3) реальному і потенційному дослідницькому вакууму про вікову специфіку психічних станів людини (передовсім йдеться про увагу), пізнавальних процесів (відчуття, сприймання, пам'ять, мислення, уява), емоційно-вольової сфери (передовсім - це воля), індивідуальнотипологічних особливостей (особливо - характер), 4) недоказовим чи малодоказовим висновкам і прогнозам про віковий розвиток людини та аналогічному використанню методів статистичної обробки отриманої емпіричної інформації, коли отримані кількісні результати розглядаються у ранзі якісних узагальнення (приклади) (Polishchuk, $2019 ; 2020)$. 


\section{Стратегія 1. Розвінчування у громадян традиційних} пізнавальних орієнтирів (життєвих стереотипів), згідно з якими знання психології дітей дошкільного віку і молодшого шкільного віку, підлітків, юнаків начебто уже попередньо обмежуються використанням, як правило, лише у системі освіти або сімейних взаємин. Насправді вони потрібні також для інженерної, економічної, юридичної психології, психології реклами, психології засобів масової інформації, психології управління, психології менеджменту, проєктування професійної кар'єри тощо і з соціальним плином часу актуалізуються для інших психологічних галузей.

Очікувана соціальна перспектива: оптимізація особистіснопрофесійних взаємин, підвищення продуктивності праці у громадян, збереження їхнього фізичного і психічного здоров'я.

Стратегія 2. Системне теоретико-емпіричне вивчення психології дорослості, яка залишається малодослідженою порівняно 3 попередніми віковими інтервалами, не лише через традиційні поперечні зрізи, а 3 допомогою лонгітюдних наукових розвідок 3 використанням експериментальних змінних. Так, “психологія літнього віку” у дорослості належить до тих наукових тем, де життєвий досвід старших поколінь надійно гуртує суспільство у ситуації наростаючих воєнних, терористичних викликів і загроз.

Очікувана соціальна перспектива: систематизація доказової інформації про віковий розвиток людини; обмеження споглядальних міркувань i висновків, які призводять до термінологічної невизначеності, хаосу у виокремленні вікових періодів життєвого шляху типу “криз середнього віку”, “кризи 30 років”, “кризи 40 років”, “кризи середини життя" тощо без доказових емпіричних розвідок чи навіть без їхньої наявності, довільного тлумачення змісту, внаслідок чого відбувається суб' єктивне тлумачення вікового місцезнаходження людини, що унеможливлює адекватні дослідницькі перспективи передовсім вікової, педагогічної, диференційної психології як наукових галузей, розроблення результативних розвивальних індивідуальних програм, рекомендацій тощо.

II. "Актуальна наукова проблематика" - це усвідомлена необхідність об'єктивного пізнання (наукового відкриття) у людини чи соціальних спільнот у конкретній сприятливій чи несприятливій) соціальній ситуації розвитку. Продуктивне дослідження передбачає тут комплексне інформаційне відображення своїх смислів у трьох історичних хронологічних площинах "минуле - теперішне майбутнє”, де останній площині (“майбутнє”) “належить вирішальна прогностична роль у розробленні новітніх фундаментальних та 
прикладних тематичних технологій 3 метою їх теперішнього i потенційного результативного застосування на основі конкретного актуального індивідуального чи групового соціального запиту. Характерно, означені смисли перебувають у сфері інтересів методології та організації наукових досліджень незалежно від галузевих наукових напрямків (Danilyan \& Dzyoban, 2019; Krajg, 2003; Malska \& Pankiv, 2020; Obidina, 2017; Yurchenko, 2017).

У зв'язку з цим у дослідницькій діяльності для виокремлення актуальної психологічної проблематики варто дотримуватися наступних методологічних настанов (приклади) (Goncharenko, 2008):

1. Сконцентруватися на одній дослідницькій тематиці, - тобто обрати першочергові пошукові пріоритети, абстрагувавшись від інших (менш важливих), що дозволяє забезпечити цілісність дослідницької процедури, а, значить, обрати методологію дослідження та узгодити логістику його етапів.

Визначатися 3 такими пріоритетами допомагає дослідницька гіпотеза, яка конструює зміст потенційної наукової теорії, завдяки якій виробляється структурований план наукової діяльності, де відображається процес постійного вдосконалення “відкритого знання”, i, зрештою, виокремлюються пізнавальні перспективи досі “невідомого знання”. На жаль, пошукове значення гіпотези з початком $\mathrm{XX}$ ст. відверто принижується, що виявляється у їі відсутності для більшості досліджень як системного структурно-функціонального положення. Однак це 1) конкретний пізнавальний орієнтир, без якого наукова праця втрачає свій функціональний сенс через сумніви в науковій достовірності отриманих результатів; провідна стратегічна ідея дослідження, спрямована на розв'язання конкретного завдання, 2) своєрідна “візитівка", “маркер”, що принаймні теоретично убезпечують наукову працю від спрощеності i деклараційності, 3) напрямок пошуку "чогось" невідомого в науці i практиці, 4) конструктивність (зрозумілість, прогностичність) наукової концепції, завдяки чому перевіряється життєдайність сформульованих методологічних положень, процес дослідження $є$ організованим i коректним, а, значить, отримані емпіричні дані є дійсно ймовірними.

Зрештою, без гіпотези неможливо увиразнити актуальну проблематику.

2. Сформулювати зрозумілу і справді важливу для професійного повсякдення i для себе дослідницьку тематику (об'єкт і предмет дослідження), розв'язання якої вдосконалює, розвиває саме свій життєвий простір (матеріальний, інтелектуальний тощо), потім - 
життєвий простір інших громадян 3 відповідними оптимістичними розвивальними перспективами.

Для цього нам варто орієнтуватися у споріднених дослідницьких темах задля уникнення їхнього паралелізму, дублювання та одноманітності змісту, уникати називати об'єктом чи предметом дослідження суб'єктів соціального процесу (учнів, студентів, учителів, батьків, навчальні ресурси тощо). Важливо бачити власний пізнавальний ракурс проблеми і не претендувати на "всезнайство", яке уже попередньо засвідчує, 3 одного боку, необгрунтовану амбітність дослідника, а 3 другого, різнопланову обмеженість його загального кругозору часто на межі професійної неспроможності до виконання наукової роботи.

Характерно, що для розуміння доказових тактичних завдань досягнення (логістика) потенційного результату необхідно розробити проєктну структурну або структурно-функціональну моделі предмета дослідження, доцільність яких виявиться у впровадженні змістовних технологій, ефективність яких перевірена у тривалому календарному дослідницькому часі (як мінімум, це 3-4 роки, тобто йдеться про лонгітюдні розвідки), а не ситуативних спробах. ефективність яких $\epsilon$ доволі малопереконливою.

3. Змоделювати зміст проблематики (як приклад, це математичне моделювання за правилами формальної системи 3 допомогою математичних операцій), що дозволить перевірити задекларовану теоретико-емпіричну спроможність своєї теорії про шляхи іiі розв'язання, забезпечить збір нової інформації, виокремить приховані суперечності, створить цілісну картину досліджуваного предмета у системі різнопланових чинників впливу, а головне унеможливить деклараційні узагальнення, які часто ні до чого не зобов'язують. У цьому контексті типовими $є$ формулювання “До питання....", "Про.....", де уже заздалегідь прогнозується виклад “не самої сутності питання”, а споглядальні суб'єктивні судження на “сутність викладу” "сутності питання” на кшталт “нам здається”.

У таких випадках ми отримуємо низку несприятливих дослідницьких явищ як пізнавальних бар'єрів на шляху до істини (приклади):

1. “Теоретизування проблеми”, або “книжкова вченість” (основна причина: відсутність належних емпіричних розвідок): 1) часто використовуються судження типу "на засадах комплексного підходу”, “системного підходу” без будь-якого пояснення їхньої специфіки у конкретній ситуації; 2) домінуе "психологія фокусу" (досліднику здається, що варто лише заявити про відкриття, вже не кажучи про застосування, і навколишня дійсність позбудеться будь 
якої несприятливої проблематики); 3) споглядальні висновки 3 претензією на “новітні узагальнення”, що лише ускладнює розуміння проблеми, формує у нового покоління дослідників хибні уявлення про стан “недостатнього розроблення", а головне, що “такими мають бути наукові узагальнення": 4) незрозумілість, очевидність, узагальнень, які насправді не потребують ніяких доведень (це “судження заради судження", де відсутня будь-яка конкретика).

2. Деклараційне використання дійсно важливого стандартного вислову типу “надійність і вірогідність результатів ... забезпечувалася використанням надійних i валідних діагностичних методик, поєднанням якісного i кількісного аналізу емпіричних даних, репрезентативністю вибірки ...”.

3. Некоректне використання методів математичної статистики, де часто віддається “данина соціальній моді". Не може бути “статистики” “заради статистики”. Дійсно, математичне вивчення зв'язків i залежностей у життєвих явищах $€$ завершеним смислом, коли базується на якісному аналізі, - тобто математичні методи не потрібно протиставляти іншим аналітичним методам (так, ніколи не втратить своєї результативності тривале природне спостереження, більше того воно має домінувати). Однак часто відбувається підміна якісного аналізу кількісними даними, які до того ж можуть розглядатися поза контекстом вікових та індивідуальних особливостей людини чи різних соціальних впливів. Також типовою помилкою $\epsilon$ використання недоказових (суб'єктивних) інтервальних шкал, тоді як психологічні проблеми - це прерогатива порядкових шкал.

Загалом "актуальна психологічна проблематика" має виразний кризовий стан. Так, у ii масштабному полі вторинним явищем залишається експериментальне вивчення психічних станів, процесів, емоційно-почуттєвої сфери, індивідуально-типологічних особливостей. Практично відсутні тематичні теоретико-емпіричні дослідження про відчуття, волю, характер, уяву, оскільки такі пошукові домагання потребують від дослідника особливої професійної підготовки із схильністю до наукового ризику. Потребує вивчення вікова динаміка структур психіки, розвитку особистості у вузьких вікових інтервалах як відображення внутрішньої логіки розвитку на тлі загальних пізнавальних тенденцій окремих вікових періодів дошкільного віку, молодшого шкільного, підліткового тощо. "Цілинною", як уже зазначалося, залишається психологічна проблематика старших вікових періодів. Громадянське суспільство потребує також розроблення тематичних соціальних технологій для ситуацій функціональної напруженості, екстремальних і надзвичайних 
ситуацій на основі реального об'єктивного соціального запиту, який, продукує, наприклад, сьогоднішня епідеміологічна ситуація і спричинена нею принципово нове соціально-психологічне повсякдення, якого людство не знало не лише з початку ХХ ст., а 3 90$\mathrm{x}$ років.

За розробленням кожної наукової проблеми постає конкретний науковець, визначальною рисою якого $є$ не лише фундаментальна підготовка, а також загальнолюдські якості, позначені культурою поведінки і культури мислення, відсутністю фарисейства, стабільним прагненням до пошуку істини.

\section{Висновки:}

1. Ігнорування у повсякденній професійній дослідницькій практиці базових смислів феноменів “актуальна наукова проблематика" чи “актуальна психологічна проблематика” обов'язково призводить до продукування догматичної, компілятивної інформації, яка, у свою чергу, стане основою для формулювання наступної схожої “проблеми”, актуальної хіба що в уявленнях іiї автора, i, зрештою, до дискредитації наукового психологічного знання.

2. Будь-яка актуальна проблематика має результативні перспективи свого доказового розв'язання лише тоді, коли вивчається у руслі об'єктивного адресного вікового та соціумного місцезнаходження особистості у системі ії життєвого шляху.

3. Розроблення актуальної психологічної проблематики завжди матиме оптимістичні перспективи, якщо іiі суб'єкти (дослідники; психологи різних виробничих сфер) налаштовані на безкомпромісний пошук варіантів ії розв'язання. Тоді у Людини формується соціальна відповідальність, нетерпимість до подвійних моральних стандартів, стабільним є задоволеність від життя, i, як наслідок, забезпечується ефективна продуктивність праці, зберігається і зміцнюється фізичне та психічне здоров'я.

\section{Conflicts of interests:}

The author declares that there is no conflict of interests.

\section{Source of support:}

This research did not receive any outside funding or support.

\section{References}

Aleksandrov, A. A. (2017). Psykhohenetyka [Psychogenetics]. Piter. https://avidreaders.ru/book/psihogenetika.html [in Russian] 
Danilyan, O.H., \& Dzyoban, O.P. (2019). Metodolohiya naukovykh doslidzhen [Scientific research methodology]. Pravo. https://pravoizdat.com.ua/image/data/Files/592/3_Metodologija_vnutri.pdf [in Ukrainian]

Ellis, A. (2002). Overcoming resistance: A rational emotive behavior therapy integrated approach (2nd ed.). Springer Publishing Co. https://psycnet.apa.org/record/2003-04406-000

Goncharenko, S. U. (2008). Pedahohichni doslidzhennya [Pedagogical researches]. Vinnytsia. https://hum.edu-lib.com/pedagogikapsihologiya/goncharenko-s-u-pedagogichni-doslidzhennyametodologichni-poradi-molodim-naukovtsyam [in Ukrainian]

Krajg, G. (2003). Psikhologiya razvitiya [Development psychology]. https://www.psyoffice.ru/3340-krajjg-grjejjs.-psikhologijarazvitija.html [in Russian]

Malska, M., \& Pankiv, N. (2020). Osnovy naukovykh doslidzhen [Fundamentals of scientific research]. LNU. https://geography.lnu.edu.ua/wp-content/uploads/2021/01/Osnovynaukovykh-doslidzhen-Pan-kiv-Malska.pdf [in Ukrainian]

Obidina, Yu. S. (2017). Filosofiya i metodologiya nauki [Philosophy and methodology of science]. http://www.imomi.unn.ru/images/uploads/2019/obidina_philosofia.p df [in Russian]

Polishchuk, V. M. (2019). Crisis behavioural symptoms set in person's age development. International Journal of Education and Science, 2(2), 51. https://doi.org/10.26697/ijes.2019.2.37

Polishchuk, V. M. (2020). Vikovyy kryzovyy rozvytok lyudyny vid dnya narodzhennya do doroslosti [Age-related crisis of human development: from birth to adulthood]. Universytetska Knyha. https://elibrary.kubg.edu.ua/id/eprint/33302/6/V_Polishchuk_VKRL _2020_IL.pdf [in Ukrainian]

Vygotskiy, L. S. (1984). Sobraniye sochineniy [Collected works]. http://elib.gnpbu.ru/text/vygotsky_ss-v-6tt_t4_1984 [in Russian]

Yurchenko, S. O., \& Yurchenko, O. Ye. (2017). Osnovy naukovykh doslidzhen [Fundamentals of scientific research]. https://www.univer.kharkov.ua/images/redactor/news/2017-1212/Yurchenko [in Ukrainian]

\section{Information about the author:}

Polishchuk Valerie Mykolayovych - https://orcid.org/0000-0002-12831640; Doctor of Psychological Sciences, Professor, Borys Grinchenko Kyiv University, Kyiv, Ukraine. 
Research interests: age development psychology, social psychology, management psychology, theoretical and methodological problems of psychology.

\section{Cite this article as:}

Polishchuk, V. M. (2021). Problematyka psykholohichnoi nauky v aktualnomu sotsialnomu vymiri [Problem issues of the psychological science in the actual social dimension]. In Yu. B. Melnyk, \& L. M. Georgieva (Eds.), Current Issues of Education and Science. 9th International Conference, CIES-2021, Riga, Latvia - Kharkiv, Ukraine, November 10-13, 2021, Conference proceedings (pp. 33-43). KRPOCH. https://doi.org/10.26697/9786177089147.2021.05 [in Ukrainian]

\section{Copyright information:}
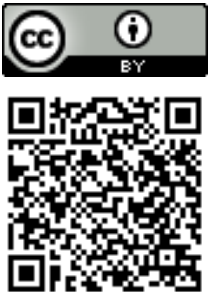

The published paper are licensed under a Creative Commons "Attribution" 4.0 Worldwide

The electronic version of this article is complete. Full or partial reproduction of article is allowed, citing to the source, author(s) and DOI. An electronic copy of the Conference proceedings in open access is available via the KRPOCH Publishing website https://publisher.culturehealth.org 